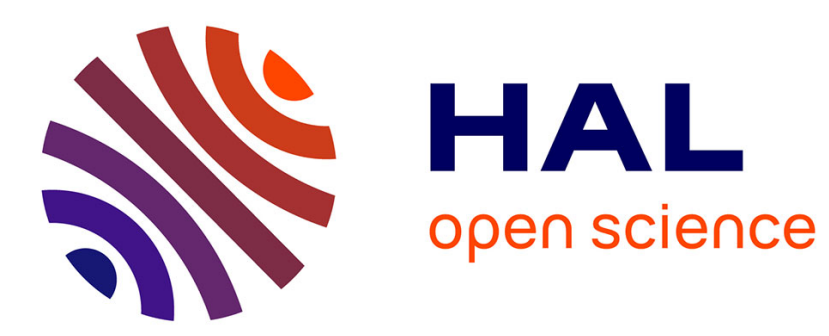

\title{
Book Review: Patterned ground: entanglements of nature and culture
}

\author{
Jack Livingston
}

\section{To cite this version:}

Jack Livingston. Book Review: Patterned ground: entanglements of nature and culture. cultural geographies, 2005, 12 (2), pp.251-252. 10.1191/1474474005eu329xx . hal-00572153

\section{HAL Id: hal-00572153 \\ https://hal.science/hal-00572153}

Submitted on 1 Mar 2011

HAL is a multi-disciplinary open access archive for the deposit and dissemination of scientific research documents, whether they are published or not. The documents may come from teaching and research institutions in France or abroad, or from public or private research centers.
L'archive ouverte pluridisciplinaire HAL, est destinée au dépôt et à la diffusion de documents scientifiques de niveau recherche, publiés ou non, émanant des établissements d'enseignement et de recherche français ou étrangers, des laboratoires publics ou privés. 


\section{reviews in brief}

Patterned ground: entanglements of nature and culture. Edited by Stephan Harrison, Steve Pile and Nigel Thrift. London: Reaktion. 2004. 312 pp. £17.95 (US \$29.00) paper. ISBN 1861891814.

Compilations of essays on the intersection of nature and culture are numerous and often uneven in their content. Patterned ground sets itself apart from this crowded genre by creating a landscape of essays that are at once familiar in their topics and yet also powerfully new by their juxtaposition with each other. The editors of the text set the stage by asking a wide range of authors to 'write short essays that discussed one element in the landscape that they are particularly passionate about' (p. 8). The result is a collection of 108 short pieces on topics ranging from drumlins to slums and tors to archives. The collection moves the reader across a mosaic field of human articulation with space. In sum, the book is a manifestation of the questions we all ask 'about the patterns we see on the ground and also about the ground on which we choose to see those patterns' (p. 45). While the individual essays are uniformly strong, the book is most notable because the editors have succeeded in turning the seeming cacophony of essay topics into a complex score with the three recurring themes of flow, site, and matter.

The themes of Patterned ground are powerful in the ability both to tie together disparate essays and to challenge the reader to reassess preconceptions of process, landscape and materiality. There is a subtle and playful lyrical connectivity to the arrangements of the essays. A single example will serve to illustrate this pattern. The third section, 'Matter', starts with Ted Benton's essay, 'Bees', which discusses the vitality of bee populations in England and also challenges us to reconsider our valuation of conservation landscapes. Diane and Tony Watson's essay, 'Pubs', redirects the image of bees by including the Beehive, a public house in Grantham, England, that has a live beehive as part of its signage. The 'Pubs' essay also includes the use of a blue pig as a sign. This representation tangentially moves the reader to the next essay, on 'Pigs' and their place in the expansion of the British empire. In this manner the reader is moved from image to theme, from theme to connection and from connection to a reframing of the everyday ground we traverse. Yet even in these subtle connections the reader is challenged to reconsider relationships by the inclusion of a comprehensive 'Notes to readers' chapter. Here the editors suggest that the book can be read out of sequence, or that some readers may find it useful not to read the essays first but rather to focus on the many images within the text. The readers in this way articulate with and re-create 
the text through their decisions on how it is read. Ultimately, Patterned ground succeeds because both the editors and the authors have created a compilation of vignettes that interrupt the reader's normal flow of experience and create renewed perceptions of place.

Slippery Rock, University of Pennsylvania

JACK LIVINGSTON

Culture and democracy: media, space and representation. By Clive Barnett. Edinburgh. Edinburgh University Press. 2003. viii +232 pp. £47.50 cloth; £16.99 paper. ISBN 0748614001 cloth; ISBN 0748613994 paper.

This book addresses numerous issues pertaining to the interdependence of culture, democracy and communication. It is a philosophical work, informed by a broad range of cultural and democratic theorists - including among others Derrida, Foucault and Habermas, an evaluative critique of whose writings forms the core of the first four chapters. In Chapter 1 Barnett considers the idea of spaces of representation, asking in particular where the public makes its presence felt through an analysis of the geographies of democratic communication. Chapter 2 examines the production of communicative spaces, while the third chapter is devoted to a critique of the concept of the public sphere as formulated by Habermas. In Chapter 4 the author looks at technologies of citizenship, re-evaluating the Foucauldian approach to understanding power. Taken together, these chapters aim to 'develop a theoretical account of the practical difference that principles of deliberation, communication and representation make to the way power is exercised upon and through practices of mediated public communication' (p. 7).

The book is also empirically grounded. Chapter 5 explores the role of constitutional law in determining the meanings ascribed to democracy when applied to the regulation of new communications technologies. In particular, Barnett charts the way in which in the latter part of the twentieth century the US First Amendment was interpreted in an essentially libertarian fashion to underpin a particular deregulatory approach to communications policy. Chapter 6 examines the contribution of European Union media policy to the process of democratising a transnational polity. Finally, Chapter 7 uses the case of South Africa to discuss issues of media and democratization, and in particular the need for a pluralistic associational culture for the functioning of a healthy democratic public sphere. These three chapters illustrate a specific aspect of Habermasian theory, but they can also be appreciated as freestanding explorations of particular communicative features in the functioning of democratic polities.

This is a work which makes demands of the reader, with the early chapters in particular requiring considerable familiarity with the ideas of key writers in democratic and cultural theory. The book would have benefited from a stronger Introduction and Conclusion which more clearly laid out the key overarching arguments and more 